\title{
Ritual songs for girls' nubility rites at Bono Takyiman, Ghana
}

\author{
Kofi Poku Quan-Baffour \\ Institute for Adult Basic Education \& Training \\ University of South Africa \\ quanbkp@unisa.ac.za
}

\begin{abstract}
Among the Bonos, particularly those within the municipal area of Takyiman, nubility rites are an important aspect of social life. The weeklong rite of passage forms a transition from girlhood to womanhood. It is a cultural norm among the Bonos of Takyiman for girls to remain virgins until their initiation. Nubility rites (bra goro) are performed to give permission or the right to marriage and for that matter sex life and child bearing. The initiation ceremony serves as an advertisement and a proclamation to community members, especially men, that a girl is of age and available for courtship and marriage. In the Bono belief a girl who falls pregnant withou: waiting for the initiation into womanhood brings a curse on the family and the community. She is described as kyiri bra (one who hates initiation and transition). During the ceremony, the girl is honoured with presents in the form of money, clothes, suitcases, and so on for keeping her virginity until she has come of age. This article outlines and discusses some of the songs sung during the weeklong nubility ceremony, their significance and the message for the initiate-the 'new woman' and her friends in the community.
\end{abstract}

Key words: nubility, rites, womanhood, education, training, virgin, puberly

\section{Introduction}

According to the cultural norms of the Akans, and for that matter the Bonos of Ghana, girls are not regarded as mature women and marriageable until elaborate rites are performed to mark their transition from girlhood to womanhood. This practice of ushering female children into womanhood or adulthood is still a significant socio-cultural event among the Bonos in spite of the influence of Christianity, formal education and Western values. The Bonos, who form a significant part of the Akan, the largest ethnic group in Ghana, occupy most parts of the Mid-West of the country. They are quite conservative in that they have refined and maintained their culture without disposing of it completely to the whims and caprices of modernity. Among the Bonos, particularly those within the municipal area of Takyiman, girls' nubility rites are an important aspect of social life. The weeklong rite of passage forms a transition from girlhood to womanhood. It is a cultural norm among the Bonos of Takyiman for girls to remain virgins until their 
initiation. Nubility rites (bra goro) are performed to give young women permission or the right to marriage and for that matter a sex life and child bearing. Sarpong $(1977,79)$ affirms that nubility, the right to marry, is only a corollary to the girl's introduction to sexual life and the words used in the songs (during the ceremony) go a very long way to emphasise this. The ceremony which lasts for one week is a form of advertisement or a proclamation to community members, particularly men, that a girl has come of age and is available for courtship and marriage.

The Bonos regard it as a taboo and a disgrace for a girl and her family if she falls pregnant before going through the nubility rites. The belief is that her action could bring a curse on the family and the community at large. A girl who falls pregnant without waiting for the initiation into womanhood is described as a kyiri bra (literally, the one who hates or dislikes to be honoured or bring honour to her family and community). Falling pregnant before being initiated is a disgrace, particularly to the family because community members might regard the particular family as a source of infidelity and not good enough to marry. The children of a kyiri bra are given funny names to indicate the circumstances of their conception. A typical name is Nimo (gossip or bad name). Until recently, such a girl and her boyfriend could be banished from their community as a punishment for the abomination.

During the weeklong ceremony the girl is honoured with presents in the form of money, clothes, suitcases, ornaments, and so on for keeping her virginity until she has come of age. Throughout the weeklong ceremony various songs are composed and sung by the elderly women of the community to mark the occasion. Among the Bonos of Takyiman a crucial turning point in a woman's life is when she comes of age and enters womanhood. In his affirmation of this fact Sarpong $(1974,71)$ writes that in sociological adulthood a distinction is also sometimes made between the access that a person is given to a sexual life, with its marital implications and the social rights and duties a person assumes as an adult in everyday life. The songs give praise to the 'new' woman and her family, particularly the parents. There are some songs which give advice to the 'new' woman regarding her marriage and the young girls in the community to emulate the good example of the initiate. This article outlines and discusses some of the typical songs sung during the initiation ceremonies, their message or their significance for the youth in the various families and the entire community.

\section{Songs to celebrate the rite of passage}

The nubility rites that usher Bono girls into adulthood consist of elaborate ceremonies which take eight days to complete. From the preparation to the end of the nubility rites different songs are composed and sung by women in the community. Each song has its own meaning, significance and lessons for the community members, particularly the youth and their parents. 


\title{
Songs sung during preparation for the nubility rites and their significance
}

As part of the preparation women and girls go to the River Apongosu to fetch white clay and fire wood. The girl's parents and immediate relatives buy smoked meat, sheep, fowls, eggs, yams, coco-yams, plantains, palm oils, a bed spread, a new bed, a mattress, pillows and a mat. During the preparations various songs are sung to mark the occasion. A week before the rites are performed a group of elderly women in the village sing songs at dawn to inform the community members of the impending important occasion. On their way from fetching the clay, water, fire wood and foodstuff the women sing to entertain and celebrate the life of the girl who is to be outdoored. The women folk sing a song in Twi entitled 'Dee emaa pe' ('What women like'). A few of the verses of the song follow:

\author{
Dee emaa pe ne apotonsu \\ Kokoo aben, nkamfo aben \\ Enso dee emaa pe ne apotonsu \\ [What women prefer is soft porridge \\ Kooko and nkamfo (type of yams) \\ have been cooked and served \\ But women prefer soft porridge \\ (locally referred to as apotonsu)]
}

This song is a proverb. It indicates that women have reasons for their choice of partners. Although there might be proposals from handsome, wealthy and powerful men, such physical things are deceptive and cannot buy love. True love which brings happiness in married life has nothing to do with the suitor's appearance, background, wealth or status. The song advises young women to look before they leap (before accepting the hand of a man). Once a girl has come of age, and she is a virgin and beautiful, all sorts of men may come and try to woo her, but not all that glitters is gold. Young women must look beyond a man's riches, status and 'looks'. The song is of particular significance in the light of prevailing poor conditions of most rural women who could easily fall prey to wealthy men who after a few years might abandon their wives and children and look for more sophisticated partners. There are some women who might not love a particular man, but because of his riches, they could pretend to love him in order to enjoy 'soft life'. Such women could run away from their husbands when the latter become poor. The song therefore has a lesson for both young women and men.

A marriage based on wealth and the promise of comfort may not last, hence young women and men must follow their hearts and their heads in marriage. It is better for two poor partners to settle down in marriage and work hard to improve their circumstances than to think that if they are able to marry a woman or man from a wealthy family the riches of their wife's or husband's family could become theirs or last forever. 


\section{Songs sung during the ceremony and their significance}

According to Bono custom, girls are to remain virgins until they reach the age of 19 and above when they are outdoored and given the right to be called women, marry, enjoy a sex life and procreate. The ceremony that proclaims a girl as a mature woman is an elaborate and important occasion. At dawn on the day the ceremony starts, a group of elderly women from the village assemble. They beat drums, bang nnawuta (twin cymbals) and sing bradwom (songs for celebrating the girl's life) to proclaim the event. From dawn to dusk of this opening day, which forms the climax of the nubility rites, women sing praises to God, the girl and her parents for remaining a virgin to this big day. Ampene (2005) affirms that a group of women engage in bragoro (celebration of life) which is sung as part of the nubility rites for Akan girls. Songs and dances for this social custom, which is the exclusive domain of women, are usually accompanied by donno (hour glass drums). The women engage in ecstatic dance and process from one end of the village to the other, announcing the coming of age of a girl or group of girls (Ampene 2005, 18).

The first song goes to Twereduampon (the Supreme Being, the one on whom if you lean you will never fall). The women sing Ose (proclaiming song) which goes like this:

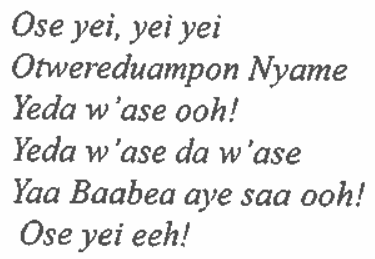

[Proclaim it loud to all!

Thanks be to you, God the Supreme Being

For Yaa Baabea has done it!

She has become a woman!

Proclaim it loud

She has reached womanhood]

The significance of the first song is seen in the recognition and acknowledgement of God by the Bonos as the Almighty and All Powerful Being who guides and protects all who put their trust in Him. God is seen as the most dependable being, Twereduampon (the mighty tree on whom if you lean you will never fall). The Bonos cannot start any venture or project without giving thanks to God and calling for His guidance and protection. After this song the singing group and community members meet at the home where the event is occurring. This is where the chief or his representative pours libation to declare the ceremony officially open. When performing the libation the officiant prays for God to bless the young woman with many children. As the libation proceeds, the women sing the officiant's words from the background: 


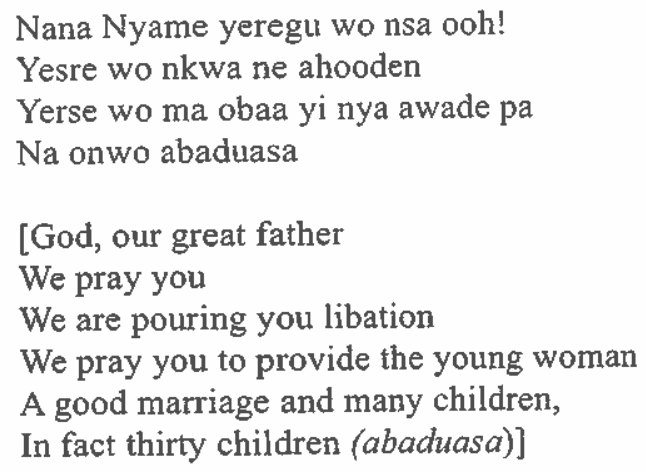

The prayer contained in the above song teaches the youth, particularly young girls, to acknowledge God (Onyame) and ask for His guidance and blessings for whatever steps they take in life. The song emphasises the expression - God first. It seems to tell the young women 'if you put God first in whatever you do $\mathrm{He}$ will bless your marriage for you to bear many children (abaduasa)'. The Bonos like all Akans are matrilineal, hence women always pray for their daughters to bear many children so that the clan may not become extinct.

Sarpong $(1977,83)$ points out that people use the rites as an opportunity to honour the girl for her good character. The rites, therefore, act as incentive for the development of the virtues of humility, co-operation, submission and helpfulness. Mothers in the village also utilise the opportunity provided by the rite of passage to study the girls in the village at close range to make a good choice of wife for their sons.

After the libation, the young woman is dressed and seated on a stool as a 'Queen' and she is given presents ranging from money, jewellery, food stuffs, clothes, beads, a bed, a mattress, curtains, linens, and perfumes to cooking pots by her parents, relatives and friends. Sheep and cocks are slaughtered and a feast is made to honour the 'Queen'. While this goes on the women's singing group parades in the streets to dance and sing songs inviting people to come adore the 'Queen', An important song. which throws an open invitation to the community members, especially the men folk, is $\mathrm{Om}$ mra (come, all):

\author{
Ommra oh! \\ Ommra ma yengoro no ooh! \\ Obaa Serwaa nuanom momra ooh! \\ Adwoa Kuruwa aye saa ooh! \\ Enti momrama yengoro no \\ [Come, all and sundry come \\ Come and let us celebrate \\ The daughter of Adwoa Serwaa, \\ Adwoa Kuruwa, has done it \\ So everyone come \\ to celebrate her life.]
}


This song not only showers praises on the girl and her family, but also indicates to the whole community that good behaviour pays. A girl who has obeyed her parents and resisted peer pressure and sexual temptations to keep her virginity until she has come of age is special and deserves an honour. She has led an exemplary life and other girls in her community must emulate her behaviour. This song is particularly important to everyone in this era when HIV/AIDS is annihilating whole communities, especially the youth who are the future generation. The youth particularly tend to lead careless lives and are more vulnerable and prone to HIV/AIDS infection. It is for this reason that other girls and their parents must come in their droves to learn from this particular girl and the occasion in order to lead better lives. They need to emulate the good example of the new woman to avoid teenage pregnancies and the possibility of contracting HIV/ AIDS and other sexually transmitted diseases (STDs). The invitation is thrown to all and sundry and indicates that this is a unique woman who has been brought up well. As an ideal woman, who is not sexually spoilt, she is an asset to both the man who will court and marry her and his family. The general belief among the Bonos is that a girl who has kept her virginity until womanhood will remain faithful to her husband unlike the one who has experimented with sex with a number of men.

Although the same is not said about males, because the Bono culture allows for polygamy, it is important to warn, counsel and encourage youths of both sexes to refrain from experimenting with sex and its concomitant socio-economic consequences.

Farming is the main activity of the Bono people, but on the occasion of a girl's nubility rite no immediate family member would go to their farms. As the ceremony reaches its climax, the women sing the song 'Enne nkoaa' (Today only) to emphasise the importance of the day. A few verses of the song follow:

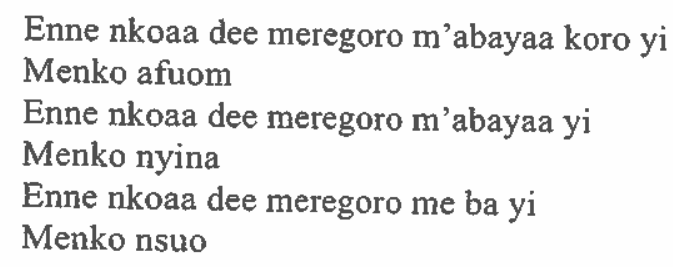

[For only today I will not go to the farm I am celebrating my only daughter's life For only today I will not go for firewood I am celebrating my child's life

For only today I will go nowhere I am celebrating my daughter's life]

The Bonos, and for that matter the people of Takyiman, are mostly peasant farmers. They constantly interact with the physical environment and cultivate the land for their livelihoods. People may stay away from their farms only when they are indisposed or there is a death in their family or in their neighbourhood. The above song therefore emphasises the importance of a girl's nubility rites among the Bono people of Takyi- 
man, which the family, relatives, friends and most of the community members sacrifice their farming activities in order to celebrate. Being a good girl who has brought honour, a good name and respect to her family, clan and the entire community, her life is worthy of celebration, hence there is no farming or fetching of firewood and water on that particular day.

\section{Songs sung to warn of post-nubility life}

After going through the weeklong initiation ceremony, the young woman is now accepted into womanhood and regarded as an adult. From then on she takes independent decisions and is responsible for her actions. However, the elderly women do not leave her to her fate. They sing songs to warn, counsel and advise the 'new' woman in various ways. Some of the songs advise the young woman to preserve rather than destroy the good conduct she has achieved. One such song (by Afriyie and Serwaa 2007) that encourages her to be consistent and steadfast in her actions is 'Gyina pintin' ('Stand firm'). A few lines are reproduced below:

Gyina pintin, mma obi nnadaa wo

To wo boase hwe hwe mu

Mma obi ara nnadaa wo

[Stand firm in your belief

Do not allow anyone to deceive you

Take your time to search for a good partner

Do not allow anyone to influence or deceive you]

The above song warns the young woman to be careful of possible temptations and deceptions. As elderly women the singers have experienced good and bad, sweet and bitter things in life and their testimony and advice given through the song is crucial in building the young woman. Once admitted to womanhood all sorts of men may take chances. It is, therefore, important for the young woman not to rush, but to take time to explore in order to know the background of all suitors who might propose to her.

The message carried by this song is very important. Some of the suitors might have dubious characters. They might be promiscuous and could infect the young woman with STDs including HIV/AIDS. There are others who might not intend to marry and could abandon her if she falls pregnant. These are serious issues a young woman should be aware of in order not to become a victim.

A song by Maame Adwoa Serwaa entitled 'Suro Nyame' ('Fear God') gives further advice and warning to the initiate. The song goes:

Suro Nyame

Mma w'ani mmre obi

Mmo krono, mmo adwaman 
Yi wo ho fir bone mu

Kae wo kumu ne wo ma

Mma w'ani mere obi

[Fear God, do not be jealous of other people's possessions

Do not steal, do not commit adultery

Always remember your husband and children

Avoid disgrace]

Many young women may become rich through stealing and prostitution. The song advises the young woman who has just started life or got married not to be lured into stealing and prostitution. The song's message is that activities like stealing and prostitution might not come free, but have a price attached in the form of illness, death, prison or disgrace. For this reason before taking any step the young woman should remember or think about her family - husband and children.

Another important song is 'Wo ne wonko' ('Go with them God') by Akua Afriyie and Akua Serwaa (2007). The song goes:

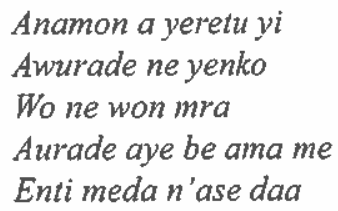

[The steps they take in life

Lord, go with them

You have done much for me]

The song's message is that life is a journey and young women are vulnerable as they take their first steps in life. For this reason the song requests God, the Supreme Being, to travel with young adults through life. God has done so much for the young woman by protecting and bringing her to this crucial stage in life. The singers thank God on her behalf and request Him to be her counsellor and advocate as she travels through life. Getting to the end of the ceremony the women sing Akua Afriyie and Akua Serwaa's (2007) song entitled 'Mo ma yena Onyame ase' ('Let us thank God'):

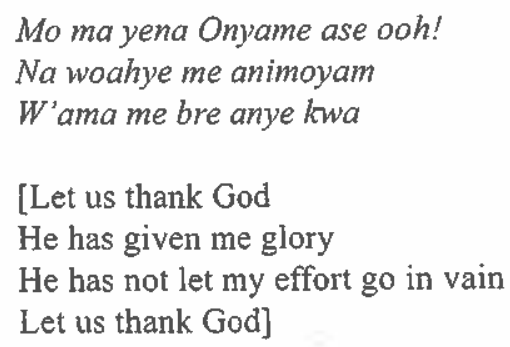


The Bonos acknowledge and recognise the presence and power of God in everything they do. Every ceremony among the Bonos starts and ends with prayers through the pouring of libation to acknowledge the presence and power of God (Onyame). The above song praises God for the honour and glory bestowed on the young woman and her family. It acknowledges God's protection and guidance in bringing up the girl to womanhood. Through God's mercy and blessings the parents and the girl did not labour in vain (me bre anye $k w a$ ). The song gives some advice to the youth, especially girls, to acknowledge God's presence in their lives, because with God everything is possible.

Having gone through the elaborate rites the girl is pronounced 'a woman' and indeed she dresses and behaves like one. Sarpong $(1977,76)$ affirms that she now wears women's beads and her attendants sing behind her:

\author{
Woni yan abodom \\ Ene me nso meyan bi \\ Fa wokon begye abodom \\ [Your mother wears precious beads (abodom) \\ Today me too will wear them \\ Stretch your neck for beads]
}

The song indicates that now that she has been admitted to womanhood the young woman should behave like a real woman - in appearance, outlook, dressing, conduct, and responsibility. She has put on a new image and discarded girlhood. As a woman she will get married, make a home, bear and raise children with all the responsibilities of adulthood. Stretching her neck to wear abodom (beads) connotes preparation for all the responsibilities that come with womanhood.

\title{
Conclusion
}

This article has illustrated the importance of the songs sung during girls' nobility rites among the Bonos of Takyiman in Ghana. As an age-old tradition and practice the rite of passage not only portrays the socio-religious aspect of Bono life, but also identifies them as a unique group of African people with a unique and rich culture. The elaborate rites and songs that are performed by women folk during the weeklong celebration teach girls the importance of respecting their bodies by keeping their virginity until they are officially admitted to womanhood.

Thus, the article concludes that in view of the devastating effects of the HIV/AIDS pandemic on African communities and for cultural identity purposes the performance of girls' nubility rites must be popularised and preserved. They must not be allowed to die away as a result of the influence of Christian and Western values. Being a respected cultural practice the rite of passage can go a long way to stemming the tide of teenage pregnancies and the spread of HIV/AIDS through its educative songs. 


\section{References}

Ampene, K. 2005. Female song tradition and the Akan of Ghana: The creative process in Nnwomkoro. Hampshire: Ashgate Publishing Ltd.

Sarpong, P. 1974. Ghana in retrospect; some aspects of Ghanaian culture. Tema: Ghana Publishing Corporation.

Sarpong, P. 1997. Girls'nubility rites in Ashanti. Tema: Ghana Publishing Corporation.

\section{Discography}

Maame Adwoa Serwaa. 1996. Suro Nyame. Krobo: Sikyi Singing Group.

Akua Afriyie \& Akua Serwaa. 2007. Gyina Pintin. Kumasi: Aboafohene Music Production Ltd.

Akua Afriyie \& Akua Serwaa. 2007. Wo ne won nko. Kumasi: Aboafohene Music Production Ltd. 